\title{
THE ROLE OF KNOWLEDGE MARKETING STRATEGIES AND RELI- GIOUS PERSPECTIVE TOWARDS TAKĀFUL AWARENESS: A STUDY BASED ON SAMMANTHURAI DIVISION IN SRI LANKA
}

\author{
Seinulabdeen Nathira Jahan ${ }^{1}$ and Mohamed Haniffa Mohamed Nairoos ${ }^{2}$ \\ ${ }^{1}$ Assistant Lecturer, Department of Islamic Studies, FIA - South Eastern University of Sri Lanka, Sri Lanka \\ ${ }^{2}$ Senior Lecturer, Department of Islamic Studies, FIA - South Eastern University of Sri Lanka, Sri Lanka
}

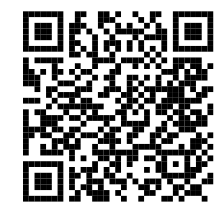

Received 17 May 2021

Accepted 28 May 2021

Published 30 June 2021

Corresponding Author

Mohamed Haniffa Mohamed

Nairoos, nairooshm@gmail.com

DOI 10.29121/

granthaalayah.v9.i6.2021.3944

Funding: This research received no specific grant from any funding agency in the public, commercial, or not-for-profit sectors.

Copyright: (C) 2021 The Author(s). This is an open access article distributed under the terms of the Creative Commons Attribution License, which permits unrestricted use, distribution, and reproduction in any medium, provided the original author and source are credited.

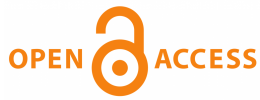

\section{ABSTRACT}

The purpose of this study is to find out the factors which enhance Takāful awareness level among general Muslim public in Sammanthurai Division. To achieve this objective, three hypotheses are taken to investigate the relationship between Takāful awareness other awareness factors such as knowledge, marketing strategies, and religious perspective. Hypothesis predicting a positive relationship between Takāful awareness level and awareness factors (Knowledge, religious perspective, and marketing strategies).Pearson correlation and regression analysis were used to measure the relationship between variables. In this study it is calculated that all three factors which Knowledge, religious perspective, and marketing strategies are crucial to enhance Takāful awareness level among general Muslim public. Furthermore, Quantitative method is used. Therefore Primary data was collected through series of questions in 200 sets of questionnaire that had been distributed among general Muslim public in Sammanthurai. And 160 were adequately respondent and considered for analysis, this formed $80 \%$ response rate. The correlation, coefficient, and regression analysis were used as method of analysis.

Keywordls: Takāful, Awareness, Knowledge, Religious Perspective, Marketing Strategies

\section{INTRODUCTION}

In worldwide Malaysia is the most famous place for Islamic banking activities. The Malaysian government promoted and developed Takāful in significant growth and most of the people conducting Islamic Insurance for their life needs. There are more than 174 full of Takāful operators around the global with an additional 133 Re Takāful operators and 47 Takāful windows (International Cooperative and Mutual Insurance Federation ICMIF, 2014). Furthermore, a large number of companies exist in 
the Middle East, Far East and even in some non- Islamic countries. The growth of Islamic Insurance has varied significantly from country to country and its success. The growth rate of Takāful market for the past few years have been recorded at more than 20 percent (Deputy Governor of bank Malaysia, 2015).

Sudan is the first country to have implemented Takāful in 1979, whereby the Sudanese Islamic Insurance Company was launched by Islamic Faisal Bank in Sudan. It was followed by some Islamic companies such as Arab Islamic Insurance Company and other companies (Mulhim \& Sabbagh, 2007). The Malaysian country also followed it in 1984 from the time of first Takāful company was established in Sudan. Now in worldwide there are more than 250 Takāful operators exist (World Takāful report 2018).

Sri Lanka is one of non-Islamic countries have legislation for the Islamic banking sector. Islamic finance was first introduced by Amana investment in year 1997, had become to be one of the growing financial sectors in Sri Lanka. Following amendment of the banking act No 30 of 1988 in March 2005, and conventional banks also have some flexibility to promote Islamic banking windows, Islamic Insurance Company and to launch Islamic financial companies in Sri Lanka (Annual Report of CBSL, 2018).

According to Sri Lanka, nowadays 27 major Insurance companies offering Insurance service including only one Islamic Insurance (IBSL, 2018). They provide much kind of products both (general and life). Sri Lanka Insurance board was regulated by the Sri Lankan's Insurance industry (IBSL, 2018) it is one of the major regulators of Sri Lanka financial system. All insurance companies registered under the regulation of insurance industry Act No 43 of 2000. Under this regulation, there are twenty-one conventional Insurance and one of the Islamic Insurance companies were registered.

In 1999 Islamic Insurance was introduced in Sri Lanka with an establishment of Amana Takāful, which recently created history in Sri Lanka. Amana Takāful was incorporated as a public company for the purpose of composite Insurance in Sri Lanka (Listed in the Colombo stock exchange (CSE) since 2006 registered under the company Act, No 07 of 2007, on $27^{\text {th }}$ of June 2007). Being the pioneer, Amana Takāful has built the acceptance of the concept from ground level. It deals with both life and General forms to be created awareness among general public. Therefore, it uses different strategies to compete with conventional insurance system (www. AmanaTakāful.lk).

\section{PROBLEM STATEMENT}

Takāful is a risk management mechanism which is recovering the losses by sharing perils and risk among policyholders based on mutual assistance, brotherhood, and solidarity (Billah \& Ma 'sum, 2019).

Takāful is being offered in Sri Lanka since 1999 there is a group of Muslims who connected with conventional insurance without having proper understanding about 
Takāful concept and not aware of Takāful existence (Ehsan Zaheed, 2015). Therefore, the Muslim preferences on Takāful should be taken into consideration by promoting Takāful awareness among Muslims to bring them into Shari'ah compliant insurance policies.Moreover, a question may arises that how can be created awareness about Takāful among Muslims? It may possible by promoting the factors which are helpful to create awareness (Al- Hameed et al., 2017).

This gives good opportunity for the researcher to investigate different Takāful awareness factors among general Muslim public based on Sammanthurai Division.

\section{RESEARCH QUESTION}

Specifically, this study has been undertaken to explore the answer to the following research question in order to solve the research problem of the study

RQ: What are the factors that enhance Takāful awareness level among general public of Sammanthurai?

\section{RESEARCH OBJECTIVE}

The main research objective of this study is developed, in order to answer to above research questions. Further the research discusses the following objectives,

\section{Primary Research Objective is:}

R01: To find out the factors which enhance Takāful awareness level among general public of Sammanthurai.

\section{Secondary Objectives are:}

R02: To define the relationship between knowledge and Takaful awareness among general public of Sammanthurai.

R03: To investigate the relationship between marketing strategies and Takaful awareness among general public of Sammanthurai.

R04: To find out the relationship between religious perspective and Takaful awareness among general public of Sammanthurai.

\section{LITERATURE REVIEW}

Awareness of Takāful has taken the attention of several researchers because; it has been empirically proven as one of the important factors that influence market preference. At the beginning, most companies have to increase awareness significantly to achieve a little gain in market preference. As awareness increase, market preference increases quickly. Despite the important of public awareness, there have been only limited studies in worldwide that measure the level of public awareness about Takāful. Actually, in general, previous scientific studies on Takāful are much less than studies on Islamic banking for instance (Kader et al. 2010). So this study aims to fill the gap by evaluating the public awareness of Takāful. 
Awareness is state or ability to perceive, to feel, or to be conscious of events, or "sensory patterns. In this level of consciousness, sense data can be confirmed by an observer without necessarily implying understanding (Mohammed Asker, 2013). Is a degree to which a products and services is concerned and recognized by positional consumers where it associates with the products and services. Moreover, it is usually expressed as an extent market's target (Lehmann and Stuart, 2010).

Several factors can create an impact on awareness of Takāful. Some of these factors discovered in the current research conducted by (Akhter, 2009; Huber, 2012; Azam \& Haseeb et al. 2016). May come out to be knowledge, marketing strategies, and religious perspective are the independent variables.

\section{Knowledge}

Knowledge can defines as understanding of something such as facts, information, descriptions or skills which is acquired through experience or education by perceiving, discovering or learning.

The products or the services, features and specification can allow the participants to present precisely and credibly with a full understating of the products and services (Queensland Government, 2014). Therefore, the knowledge is one of the necessary tools to create awareness among the general public about Takāful. Literature shows a positive relationship of knowledge and insurance. For instance, the research was done by (Browne, 1993) an international analysis of life insurance demand. In case of Takāful knowledge found a significant positive impact on Takaful awareness and have a positive impact on customer perception to shift the insurance company from traditional insurance to Takāful.

The knowledge level of the household also represents a positive attitude toward life insurance demand and knowledge level of household always shows a positive intention towards demand of insurance (Azam et al. 2016). It is most important factor that influences the demand for family Takaful (Outreville, 1996; \& Truett, 1990). Finding of the research shows a positive relationship between insurance policy coverage consumption and knowledge. Increase in knowledge, enhances the Takaful awareness among general public. Therefore it is hypothesized that;

\section{H1: knowledge has an impact on Takaful awareness level Marketing Strategies}

Is the process of making a product or service available for the consumer or business user who needs it? This can be done directly by the producer or service provider, or using indirect channels with marketers or intermediaries.

Therefore, ongoing attempt made by the Takaful providers to improve their product protection and submission program through the distribution channels is the One of the ways is to improving awareness level amongst the Muslims (Muhammad, Hamjah, \& Ghani). Based on the research finding Hussain \& Rahman, 2016 the result was discovered that the word of mouth and mass media have a huge influence on subjective norm and consequently, the subjective norm can influence the intentions to participate in Takāful. According to Salman and Htay (2014) distribution channels 
are essential to pull the customers in order to try Takaful products. So, the Takāful operators should also build more efficient distribution and delivery channel to reach the prospective customers.

The research was conducted by (Hamid \& Rahman, 2011) Marketing strategies such agents positively connect with awareness level of takāful. Previous researchers reveal the fact that performance is positively related to awareness. Moreover, literatures proved that there are different marketing strategies such as agents, salespersons, media, relatives and internet are influencing positively on awareness level of general public. Therefore, it is hypothesized that:

\section{H2: Marketing strategies has an impact on Takaful awareness level \\ Religious Perspective}

The appearance of Islamic insurance companies is often relevant to the teaching of Islam and in line with the wish of Muslims to stay all factors of their life in according to the lessons of Islam.

Islamic products such as Takaful has introduced as a new industry in financial institutions. However, its concept and features are already have been defined in holy Qur'an and Sunnah before 1400 decades ago. Takaful companies are often relevant to guide Islam. As a Muslims, it is required by Islam to live accordance with Shari'ah. Therefore, religion has positive impact on Takaful awareness level. For an example a research was done by Jahya, 2004 it shows that a person's religious perspective has an impact on the person's mind-set towards in Takāful scheme.

Another research finding was shown that, the awareness of Takaful is associated with belief about Islamic fundamentals on religious and social goals (Maysami, \& Williams, 2006). According to Iqbal et al, 2016 he found that majority of customers has awareness about Takāful and agree that Takāful companies are in compliance with Shari'ah regulations. The reason was found as majority of customers (47\%) aware about Takāful for the religious reasons not for the opportunity of saving plane or profitability purpose. Based on Abdullah, \& Gustina, 2012 religion is significantly related to the demand for family Takaful.Thus, religious perspective has significant positive impact on Takaful awareness level of general public. Therefore, from above literature, it is hypothesized that;

\section{H3: Religious perspective has an impact on Takaful awareness level RESEARCH METHODOLOGY \\ Data Collection M ethod}

The data of this research is to be collected as primary and secondary sources.

\section{Primary D ata}

Primary data will collect through the distribution of self-administered questionnaire it will be distributed among 200 general Muslim people in Sammanthurai. The questionnaire will be categorized and will consist of sets of questions related to knowledge of Takāful as well as awareness of Takāful.

\section{Secondary D ata}


Secondary data will include information obtained from books, journal articles, newspapers, magazines and other online resources.

\section{Data Analysis}

For the statistical analysis, the researchers will apply Statistical Package for social Science (SPSS) 25.0 computer software package under which person Correlation, Regression analysis tests will be calculated to analyze the primary data will obtain from the questionnaire.

\section{Research Sample}

Research was undertaken on Awareness of Takāful among Muslims. Data will be gained among 200 general Muslim people from 12 divisions out of 51 divisions in Sammanthurai through questionnaires to completing this research in perfect manner.

\begin{tabular}{|c|c|c|c|c|}
\hline S.NO & Division & $\begin{array}{c}\text { Muslim } \\
\text { Population }\end{array}$ & Sample & $\%$ \\
\hline 01 & Sammanthurai 01 & 1014 & & \\
\hline 02 & Sammanthurai 02 & 1710 & & \\
\hline 03 & Sammanthurai 03 & 1353 & & \\
\hline 04 & Sammanthurai 04 & 954 & & \\
\hline 05 & Sammanthurai 05 & 808 & & \\
\hline 06 & Sammanthurai 06 & 621 & 200 & $100 \%$ \\
\hline 07 & Sammanthurai 07 & 1187 & & \\
\hline 08 & Sammanthurai 08 & 1162 & & \\
\hline 09 & Sammanthurai 09 & 1662 & & \\
\hline 10 & Sammanthurai 10 & 958 & & \\
\hline 11 & Sammanthurai 11 & 711 & & \\
\hline \multirow[t]{2}{*}{12} & Sammanthurai 12 & 921 & & \\
\hline & $\begin{array}{c}\text { Total number of } \\
\text { populations }\end{array}$ & 13,061 & & \\
\hline
\end{tabular}

\section{Conceptual Frame Work}

Knowledge, marketing strategies, and religious perspective are taken as research variables to evaluate the public awareness of Takāful 


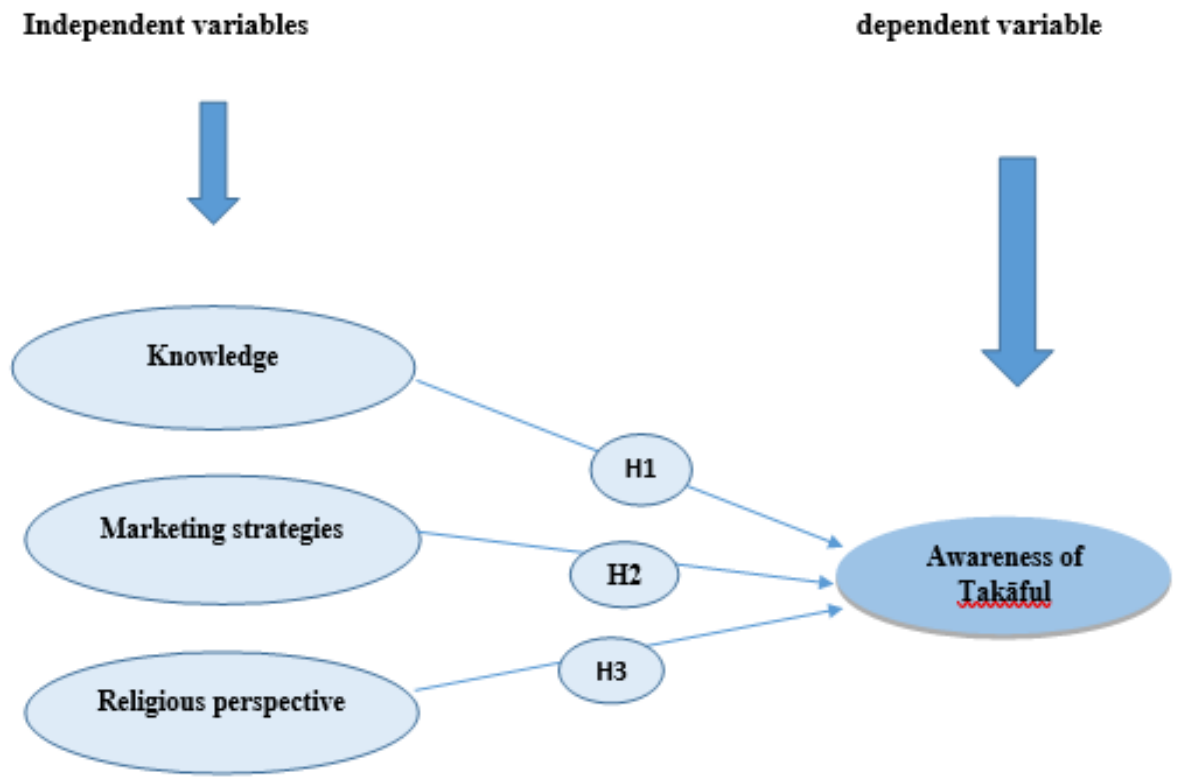

\section{RESULTS AND ANALYSIS}

\section{Check Reliability Coefficient of Research Measures}

Cronbach's coefficient alpha values were estimated to examine the internal consistency of the data (Field, 2009). More specifically, alpha is a lower boundary for the true reliability of the survey. A reliable measure in quantitative approach can be described as achieving consistent results in different research situations (Swanson \& Holtan, 2005).

The Reliability analysis results of current study shows that all the 17 items were reliable to measure the opinions of potential respondents. The Reliability measures are shown in Table 2 below:

\begin{tabular}{cccc}
\hline \multicolumn{5}{l}{ Table 2 Reliability of Instrument } & & \\
\hline Scale & No. of item & Cronbach's alpha & Type \\
\hline Knowledge & 05 & 0.88 & High Reliability \\
\hline Marketing strategies & 06 & 0.83 & High Reliability \\
Religious perspective & 06 & 0.82 & High Reliability \\
\hline Awareness & 05 & 0.71 & High Reliability \\
\hline
\end{tabular}

The above Table 2 demonstrates the reliability of each dimension of the questionnaire. Alpha values for all scales are more than the recommended value by (Nunnally, 1978) that is at least 0.7. Based on above results, all the items of each variable were finalized for survey. 


\begin{tabular}{|c|c|c|c|c|c|}
\hline & & Knowledge & Marketing & Religion & Awareness \\
\hline \multirow[t]{3}{*}{ Knowledge } & Pearson Correlation & $.808^{* *}$ & $.708^{* *}$ & $.777^{* *}$ & 1 \\
\hline & Sig. (2-tailed) & & .000 & .000 & .000 \\
\hline & $\mathrm{N}$ & 160 & 160 & 160 & 160 \\
\hline \multirow[t]{3}{*}{ Marketing } & Pearson Correlation & $.708^{* *}$ & 1 & $.678^{* *}$ & $.777^{* *}$ \\
\hline & Sig. (2-tailed) & .000 & & .000 & .000 \\
\hline & $\mathrm{N}$ & 160 & 160 & 160 & 160 \\
\hline \multirow[t]{3}{*}{ Religion } & Pearson Correlation & $.777^{* *}$ & $.678^{* *}$ & 1 & $.729^{* *}$ \\
\hline & Sig. (2-tailed) & .000 & .000 & & .000 \\
\hline & $\mathrm{N}$ & 160 & 160 & 160 & 160 \\
\hline \multirow[t]{3}{*}{ Awareness } & Pearson Correlation & 1 & $.777^{* *}$ & $.729^{* *}$ & 1 \\
\hline & Sig. (2-tailed) & .000 & .000 & .000 & \\
\hline & $\mathrm{N}$ & 160 & 160 & 160 & 160 \\
\hline
\end{tabular}

\section{Correlations}

The person correlation of knowledge and Takāful awareness is, $r=0.808$, is strongly positive. Therefore, there is strong positive correlation between knowledge and Takāful awareness. So, hypotheses H1 can be accepted and H0 can't be accepted. Therefore, it can be statistically concluded that knowledge is significantly correlated with Takāful awareness level. It means when knowledge about Takāful increase awareness will also be increased.

The person correlation of Marketing strategies of Takāful awareness is $r=0.708$, is strongly positive. Therefore, there is strong positive correlation of coefficient between Marketing strategies and Takāful awareness. So, hypotheses H1 can be accepted and H0 can't be accepted. Therefore, it can be statistically concluded that there is a significant positive relationship between Marketing strategies and Takāful awareness. It means when marketing strategies of Takāful increase awareness will also be increased.

There was a significantly strong correlation between Takāful awareness and religious perspective, $r=0.777, r>0.5$ the results suggest that the religious perspective has the high strong positive relationship with Takaful Awareness. Thus, if religious perspective increase awareness also will be increased.

\begin{tabular}{ccccc} 
Model & $\mathbf{R}$ & R Square & Adjusted R Square & Std. Error of the Estimate \\
1 & $.862^{a}$ & .743 & .738 & .58686 \\
\hline
\end{tabular}

\section{Model summary}

The coefficient of determination ( $\mathrm{R}$ square) is the proportion of variation in the dependent variable (awareness) explained by the regression model. If $\mathrm{R}$ square is relatively higher than $50 \%$ than the model can adequate and if $\mathrm{R}$ squared higher than $75 \%$, then the model can be very good adequate and if R squared higher than $50 \%$, then the model can be good adequate. 
According to the model summary table $\mathrm{R}$ square is 0.743 than the model can be good adequate. Since, R square $=0.743$ indicates that $74.3 \%$ of shared variation of the variability in awareness (dependent variable) is explained its linear relationship with the factors (Religion, Marketing, Knowledge).

Table 4 ANOVA ${ }^{a}$

\begin{tabular}{ccccccc}
\hline Model & & Sum of Squares & df & Mean Square & F & Sig. \\
& Regression & 155.536 & 3 & 51.845 & 150.534 & $.000^{b}$ \\
\hline \multirow{2}{*}{1} & Residual & 53.728 & 156 & .344 & & \\
& Total & 209.264 & 159 & & & \\
& & & & & & \\
\end{tabular}

a. Dependent Variable: Awareness

b. Predictors: (Constant), Religion, Marketing, Knowledge

The above table indicates that the regression model predicts the dependent variable significantly well. The significant column indicates the statistical significance of the regression model that was run. Here, $p=0.000$, so, which is less than 0.05 , then reject $\mathrm{HO}$ and indicates that; overall, the regression model statistically significantly predicts the outcome variable. The result of the test indicate that the null hypotheses should be rejected in favor of the alternative that with $95 \%$ confidence.

Therefore, there is enough evidence to support for alternative hypothesis. That means there is positive relationship between awareness and knowledge

\begin{tabular}{|c|c|c|c|c|c|c|}
\hline \multirow[t]{2}{*}{ Model } & & \multicolumn{2}{|c|}{$\begin{array}{l}\text { Unstandardized } \\
\text { Coeffi- } \\
\text { cients }\end{array}$} & \multirow[t]{2}{*}{ Standardized Coefficients } & \multirow[t]{2}{*}{$\mathbf{T}$} & \multirow[t]{2}{*}{ Sig. } \\
\hline & & B & Std. Error & & & \\
\hline \multirow[t]{4}{*}{1} & (Constant) & -.405 & .166 & & -2.441 & .016 \\
\hline & Knowledge & .471 & .076 & .435 & 6.212 & .000 \\
\hline & Marketing & .481 & .076 & .378 & 6.296 & .000 \\
\hline & Religion & .155 & .078 & .135 & 2.001 & .047 \\
\hline
\end{tabular}

a. Dependent Variable: Awareness

According to the coefficient table:

$$
\begin{aligned}
\beta 0 & =-.405 \text { (Constant) } \\
\beta 1 & =(.471) \text { (knowledge) } \\
\beta 2 & =(.481) \text { (Marketing) } \\
\beta 4 & =(.155) \text { (Religion) }
\end{aligned}
$$

Furthermore, the standardized beta in Table 5 acts as a correlation coefficient. It determines the extent of correlation of independent variables with the dependent variable.

This simply indicates that there is positive relationship between awareness and knowledge. Means knowledge is positively correlated with awareness. Further it 
can be expected that when knowledge increase by one, the Takāful awareness will be increased by 0.471 .There is positive relationship between awareness and marketing strategies. Means marketing strategies is positively correlated with awareness. Further it can be expected that when marketing strategies increase by one, the Takāful awareness will be increased by 0 . 481.it simply indicate that there is positive relationship between awareness and Religious perspective. Means Religious perspective is positively correlated with awareness. Further it can be expected that when Religious perspective increase by one, the Takāful awareness will be increased by 0.155 .

\section{CONCLUSION AND RECOMMENDATION}

While doing this research, it was observed that there are different factors which are promoting Takāful awareness level among general Muslim public of Sammanthurai. These factors are namely knowledge, marketing strategies, and religious perspective.

Knowledge is one of the major factors which effect Takāful awareness. If there increase in knowledge among the general public will increase Takāful awareness. Both knowledge and Takāful awareness has a strong relationship with each other. Therefore, knowledge is needed to promote Takāful awareness.

Marketing strategies are also one of the best ways to enhance Takāful awareness. Marketing strategies have also the direct relationship with Takāful awareness. Increase in the role of marketing strategies among the general public will increase the Takāful awareness. Both marketing strategies and Takāful awareness has a strong relationship with each other.

On the other hand, religious perspective is also one of the factors which has relationship with Takāful having good contribution to promote Takāful awareness level among general public of Sammanthurai. It also found that if religious perspective increase Takāful awareness also be increased. Therefore, both religious perspective and Takāful awareness has a strong relationship with each other to enhance Takāful awareness.

Based on the analysis the researcher has recommended the following recommendations as suggestions. As for the researcher concerned the above problem statement following recommendations are considered for useful adapt by Takāful operators.

- Takāful companies should train their employees like agents, brokers and salespersons that how to create awareness among people also send them to attend the courses and seminars related to Takāful to enhance they're in delivering the information to the public.

- Less number of Marketing channelsare not enough to enhance Takāful awareness. Thereforemust increase in marketing channels such as salespersons, agents, radio, internet, television, and brokers also be increased the advertisements, in order to attract the public to know about Takāful. 
- Frequently conduct free workshops and programs for the public to make them as known about Takāful concepts and principles by Takāful companies.

- The ministry of education might suggest the schools and universities across the country to increase the number of subjects related to Islamic finance and Islamic commercial jurisprudence.

- The operators should also work hard in differentiating themselves from the conventional insurance services which would build new reputation. Besides, they should win people trust and confidence.

\section{REFERENCES}

Aabdeen, K. Z. (2019). Takaful-The Islamic Way Of Insurance. Retrieved from Http://Www .Takaful

\&amp; Mehdi, \& Sadeghi. (2010). The Evolution Of Islamic Insurance - Takaful: A Literature Survey. Journal of "Insurance Markets And Companies, 1(2).

Difference Between Takāful And Conventional Insurance" Malaysia, Retrieved From Www. (2020). Takaful Malaysia News Bulletin.

Different Between Conventional And Islamic Insurance, Retrieved From Www. (2019). Sheihan Insurance Company.

Guiding Principles On Governance For Takaful (Islamic Insurance) Undertakings. (2009). In and others (Ed.), .

Hasan, K. M., Kayed, N., \& Oseni. (2013). Introduction To Islamic Banking And Finance. England.

Iqbal, M. M., Khan, M. U., Ayaz, S., \& Qazi, S. (2016). Customers' Preferences And Awareness Towards Takaful Coverage In Pakistan..

Jaffer, S. (2019). Islamic Insurance: Trends, Opportunities And The Future For Takāful, Retrieved From Www.

Kasim, N., Htay, S. N. N., \& Salman, S. A. (2016). The Religious Perspective of Takaful as Ethical Insurance. Mediterranean Journal of Social Sciences, 7(4), 96-96. Retrieved from https://dx.doi.org/10.5901/mjss.2016.v7n4p96 10.5901/mjss.2016.v7n4p96

Malaysia, T. I. (n.d.). A Survey Of Malaysian Consumers. International Journal Of Business And Social Science, 9(1).

Mansoor, K. A., Masduki, R. M. N., \& Mohammad, M. (2015). A Study On Factors Influencing Muslim's Consumers Preferences Towards Takaful Products In Malaysia. Management Studies And Economic Systems, 170-186.

Mokhtar, H. S. A., Aziz, I. A., \& Hilal, N. M. (2017). Corporate demand for general takāful in Malaysia. ISRA International Journal of Islamic Finance, 9(2), 164-184. Retrieved from https://dx.doi.org/10.1108/ijif-08-2017-0024 10.1108/ijif-08-2017-0024

Norlida, A. M., Rosemaliza, A. R., \& Ibrahim, Y. (2004). Awareness And Ownership Of Family Takaful Scheme Among Muslim Community In Malaysia. The Journal Of Mua'malath And Islamic Finance Research, 1(1).

Qaiser, R. (2020). Islamic Insurance, Retrieved From Www.

Sadegh, M. (2010). The Evolution Of Islamic Insurance - Takaful: A Literature Survey. Journal Of "Insurance Markets And Companies, 1(2).

Salleh, M. C. M., \& \&amp;laksana, N. N. M. (2018). Awareness Of Flood Victims In The EastCoast Region Of Malaysia Towards The Takaful Flood Policy: A Cross Tabulation Anal- 
ysis Based On Demographic Variables. Management \& Accounting Review, 45-58.

Salman, S. A. (2014). Contemporary Issues In Takaful (Islamic Insurance), 210-210.

Salman, S. A., \& Htay, S. N. N. (2014). Insurance In The Light Of Religious Teaching And Ethics: A Case Study Of India. Journal Of Scientific Research, 19(2), 299-299.

Salman, S. A., Rashid, H. M. A., \& Hassan, R. (2017). Awareness And Knowledge Of Insurance And Takaful In India A Survey On Indian Insurance Policy Holders. Man In India.

Soualhi, Y., \& Shammari, A. R. (2015). Indicators Of Takaful Awareness Among Kuwaitis. Journal Of Islamic Banking And Finance, 3(2), 75-89.

Srikuntanti, S., \& Askar, M. (2013). Perception On Takāful Business: A Case Of Sekolah Menengah Kebangsaan. Lundu, IBFIM.

Ustaoglu, M. (2015). Understanding And Attitudes Towards Interest Free Insurance (Takaful) Services Evaluation By Education Level. Journal of Asian And African Studies, 50(4), 445-456.

Yusof, F., Ismail, . W., \& Abdullah. (2011). Fundamentals Of Takaful. IBFIM. 